\title{
ANALISIS PENGEMBANGAN INDUSTRI DAN PERSEPSI KEPALA DESA DI KAWASAN PERUNTUKAN INDUSTRI: KASUS DI KABUPATEN KARAWANG
}

Oleh:

Andin H. Taryoto, Kamsiah, Ina Restuwati, Tuti Susilawati

Dosen Jurusan penyuluhan Perikanan Sekolah tinggi Perikanan

\begin{abstract}
Abstrak
Perkembangan perekonomian suatu negara berkembang secara umum diwarnai kecenderungan perubahan dari dominasi sektor pertanian menuju dominasi sektor industri dan jasa. Secara administrasi pemerintahan, kecenderungan ini akan juga terjadi sejak dari tingkat propinsi sampai dengan tingkat desa. Kepala Desa sebagai pimpinan Desa dinilai memiliki peran strategis dalam menyikapi perkembangan tersebut. Analisis dengan demikian ditujukan untuk mengidentifikasi sejauh mana persepsi dan tindakan Kepala Desa desa dalam konteks ini. Kabupaten Karawang dipilih mengingat posisinya sebagai salah satu kabupaten yang ditetapkan sebagai Wilayah Pengembangan Industri di Jawa Barat. Pengembangan industri dinilai memiliki dampak positif bagi masyarakat desa. Namu demikian tidak dipungkiri pula bahwa terdampat sejumlah dampak negatif yang harus dihadapi.
\end{abstract}

Kata Kunci: pengembangan industri, dampak pengembangan industri, persepsi Kepala Desa

\section{PENDAHULUAN}

\section{Latar Belakang}

Dalam Undang-undang Desa No. 6 tahun 2014 dinyatakan secara eksplisit pada pasal 26 ayat 1 bahwa Kepala Desa bertugas menyelenggarakan Pemerintahan Desa, melaksanakan Pembangunan Desa, pembinaan kemasyarakatan Desa, dan pemberdayaan masyarakat Desa. Selanjutnya dalam pasal 2 dinyatakan bahwa terdapat 15 tugas dan kewenangan Kepala Desa, sejak dari memimpin penyelenggaraan pemerintahan desa, mengangkat dan memberhentikan perangkat desa, mengembangkan kehidupan sosialbudaya masyarakat, sampai kepada menyelenggarakan wewenang yangg terkait dengan peraturan perundang- undangan yang berlaku. Hal ini menunjukkan bahwa peran Kepala Desa berdasarkan Undang-undang No. 6/2014 adalah sangat penting; seorang kepala desa dituntut untuk benar-benar mampu menyelenggarakan pemerintahan desa dengan baik, karena dapat dikatakan bahwa berdasarkan Undang-udang tersebut, desa merupakan unit pemerintahan yang mandiri, serupa dengan negara, namun dalam skala yang lebih kecil (Prambudi, 2014).

Dalam pada itu, analisis teori-teori pembangunan yang ada, menyebutkan bahwa akan terjadi pergeseran aktivitas suatu negara, dari yang didominasi oleh kegiatan pertanian, menjadi bergeser ke kegiatan industri. Menurut Ishak S. (2008), misalnya, meskipun belum terlalu nyata, telah terjadi pergeseran 
sektor unggulan di kabupaten Tasikmalaya dari sektor pertanian kesektor yang lain pada tahun 20042006, terutama ke sektor konstruksi dan perdagangan. Hal ini perlu diperhatikan secara khusus, karena diidentifikasi bahwa sektor pertanian mampu menyerap tenaga kerja lebih banyak daripada sektor konstruksi maupun perdagangan. Hal yang hampir bersamaan dinyatakan oleh Pambudi (2011) untuk propinsi Jawa Tengah. Dari data tahun 2004-2008, Pambudi menemukan bahwa di Jawa Tengah penyerapan tenaga kerja sektor pertanian lebih besar dibandingkandengan sektor industri, namun tenaga kerja yang terserap kesektor pertaniansemakin berkurang sedangkan penyerapan tenaga kerja sektor industri semakinbertambah selama tahun 2004-2008. Pambudi kemudian menyimpulkan bahwa telah terjadi perubahan struktur ekonomi di Provinsi Jawa Tengah dari sektor tradisional ke sektor modern; sektor industri menjadi sektor unggulan dan memiliki kontribusi danpertumbuhan yang besar dalam penyerapan tenaga kerja dari pada sektor pertanian, sehingga terjadi pergeseran dalam penyerapan tenaga kerja di ProvinsiJawa Tengah.

Dalam konteks desa, maka posisi Kepala Desa menjadi salah satu faktor yang harus dipertimbangkan dalam upayamemahami pergeseran kegiatan perekonomian di tingkat desa; Kepala Desa dinilai memiliki peran cukup nyata dalam mempengaruhi pergeseran kegiatan perekonomian di desa yang bersangkutan. Aspek inilah yang menjadi perhatian utama dalam penelitian ini. Kabupaten Karawang dipilih sebagai lokasi penelitian mengingat kabupaten ini merupakan salah satu kabupaten yang cukup benyak diindikasikan mengalami pergeseran kegiatan perekonomian dari pertanian ke industri, mengingat statusnya sebagai wilayah yang memiliki potensi-potensi kawasan industri di luar Jadebotabek (Alexander, 2014)

\section{Tujuan Kajian}

1. Melakukan analisis terhadap Konsep Dasar Pembangunan di Indonesia

2. Melakukan analisis Perkembangan Kawasan Industri di Kabupaten/Kota di Indonesia

3. Mengetahui kebijakan dan kegiatan yang telah dilakukan terkait dengan pengembangan Industri di Karawang

4. Mengidentifikasi persepsi Kepala Desa tentang pembangunan industri di wilayah desanya

\section{Metoda Analisis}

Pendekatan kajian yang dilakukan adalah analisis Deskriptif, ditunjang oleh pendekatan kualitatif maupun kuantitatif untuk menjelaskan aspek-aspek dalam cakupan kajian. Analisis diawali dengan deskripsi tentang konsep Dasar Pembangunan, yang menggambarkan dinamika konsep Pembangunan yang dikenal selama ini. Analisis dilanjutkan dengan ilustrasi berbagai perkembangan pembangunan yang ada pada beberapa daerah di Indonesia.

Deskripsi berikutnya berkaitan dengan analisis tentang perkembangan Kawasan Industri di Indonesia, berikut beberapa ilustrasi kawasan industri di beberapa kabupaten/kota. Sampai pada bagian ini, data dan informasi yang digunakan terutama adalah data dan informasi sekunder, yang diperoleh dari referensi dan pustaka yang ada, maupun 
data dan informasi melalui media internet dan digital. Selanjutnya secara khusus dibahas tentang analisis kawasan industri di Kabupaten Karawang, berikut implikasi terhadap perkembangan wilayah pedesaan yang berdekatan dengan kawasan-kawasan industri yag ada di Kabupaten Karawang. Informasi langsung dari para Kepala Desa kasus menjadi sumber utama analisis pada bagian ini, berdasarkan daftar pertanyaan yang diajukan khusus kepada para Kepala Desa kasus yang berada di wilayah kawasan industri. Sebagai pembanding dipilih satu kecamatan yang tidak berada di wilayah yang berdekatan dengan kawasan Industri, agar dapat diperoleh keseimbangan informasi dari desa-desa tersebut.

\section{HASIL DAN PEMBAHASAN}

\section{Analisis Konsep Dasar Pembangunan}

Pembahasan tentang Teori Pembangunan yang menyangkut sektor pertanian secara luas dan industri, tidak dapat dilepaskan dari pemikiran Rostow (1960) yang mengilhami pemikiranpemikiran berikutnya tentang proses pembangunan. Rostow menyatakan bahwa pembangunan suatu negara akan melalui tahapan-tahapan tertentu, dimana pada masing-masing tahap negara yang bersangkutan memiliki ciriciri yang tertentu pula. Indonesia pada masa pemerintahan Presiden Suharto pernah mengadopsi pemikiran Rostow ini, dalam pidatonya pada tanggal 1 Maret 1993 di forum Sidang Umum MPR, yaitu dengan menyatakan bahwa pada waktu itu Indonesia telah berada pada tahap bersiap untuk tinggal landas (Saksono, 2013). Tahap-tahap yang harus dilalui oleh suatu negara menurut pemikiran Rostow adalah: (1) Tahap Masyarakat Tradisional (traditional society); (2) tahap Pra-kondisi untuk Tinggal Landas (preconditions for takeoff); (3) Tahap Tinggal Landas (takeoff); (4) Tahap Pemantapan (drive to maturity); dan terakhir (5) Tahap Masyarakat dengan tingkat Konsumsi Tinggi (the age of high mass consumption). Masing-masing tahap memiliki ciri-ciri tersendiri.

Tahap Masyarakat Tradisional dicirikan oleh kegiatan pertanian atau usaha primer, yang didominasii oleh kegiatan perburuan dan pengumpulan hasil alam. Teknologi yang digunakan sangat sederhana, tidak ada pembagian kegiatan didalam masyarakat, serta menilai perubahan sebagai sesuatu yang harus dihindari. Tahap Pra Kondisi untuk Tinggal Landas dicirikan oleh masyarkat yang mulai memerlukan bahan mentah dari luar, sementara kegiatan pertanian sudah makin produktif dan mulai diarahkan ke usaha komersiil, sarana dan prasara produksi mulai dibangun, mulai ada pembagian tugas dalam kelompok-kelpompok masyarakat, memungkinkan adanya mobilitas sosial dalam masyarakat, serta mulai terbentuk identitas negara secara nasional. Tahap Tinggal Landas dicirikan oleh tingkat urbanisasi menaik, terjadi loncatan-loncatan teknologi, makin menonjolnya permintaan barangbarang sekunder/konsumtif. Tahap Pemantapan dicirikan oleh perkembangan industri-industri maju, manufaktur bergeser ke barang-barang tahan lama dan barang konsumsi, pesatnya perkembangan transportasi, serta pesatnya pengembangan infrasturktur pelayanan masyarakat. Tahap Masyarakat dengan tingkat 
Konsumsi Tinggi dicirikan oleh dominasi sektor Industri, berkembangnya permintaan barang konsumsi berkualitas, pendapatan jauh melampaui kebutuhan. Masalah produksi dan investasi sudah tidak menjadi masalah,tetapi sudah mengaranh pada pengembangan kesejahteraan sosial (social welfare).

Dengan memperhatikan tahaptahap perkembangan yang dinyatakan Rostow, dapat kemudian dinyatakan bahwa kegiatan-kegiatan industri primer seperti pertanian dan perikanan akan makin digeser oleh industri sekunder dan tersier. Kenyamanan hidup menjadi salah satu tolok ukur utama, sementara pendapatan masyarakat telah mencapai tingkat yang sangat memadai. (Gambar $1)$.

Teori Rostow mendapat cukup banyak kritikan. Salah satu kritik utama terhadap Rostow adalah ketidakkonsistenan dalam memandang dikotomi sektor pertanian dengan Industri (Adzani, 2012). Pada awalnya, Rostow memandang pertanian sebagai kegiatan yang dapat menjadi sumber kesejahteraan masyarakat. Dalam pembahasan selanjutnya, Rostow berbalik mengesampingkan sektor pertanian, dan menempatkan sektor Industri sebagai unggulan. Dalam hal ini analisis Kariyasa (2006) menunjukkan bahwa Indonesia telaah mengalami pergeseran ataupun transformasi struktural dalam perkembangan perekonomiannya, yang ditunjukkan dengan kenyataan bahwa sektor primer, terutama sektor pertanian, sedcara berangsur mulai tergeser oleh sektor industri pengolahan da manufaktur, perdagangan, jasa keuangan, serta angkutan dan komunikasi. Supadiyanto (2014) secara hiperbolik menyatakan bahwa Indonesia saat ini dalam keadaan "darurat sektor pertanian", mengingat kebanyak petani telah berusia lebih dari 50 tahun, sementara generasi muda cenderung untuk tidak mau terlibat dalam kegiatan pertanian langsung

Dalam perkembangannya, daerahdaerah mengembangkan pendekatan pembangunan yang tidak lagi terlalu kaku meng-kotak-kan pembangunan antar sektor. Pendekatan yang digunakan adalah pendekatan totalitas, yang lebih menekankan pendekatan kesejahteraan masyarakat. Sebagai ilustrasi, Kabupaten Cilacap memiliki program Bangga Membangun Desa. Terdapat empat pilar yang menjadi penopang kebijakan program Bangga Mbangun Desa tersebut (Swa Online, $\underline{6}$ November 2013). Pilar pertama adalah pendidikan. Hal ini terutama mengacu pada pendapat bahwa pendidikan merupakan sarana bagi masyarakat bawah untuk meningkatkan derajat hidupnya. Motto untuk pilar pertama adalah "Cilacap Cerdas". Pilar kedua adalah kesehatan. Warga miskin kabupaten Cilacap saat ini dapat berobat di Puskesmas dan rumah sakit dengan menggunakan fasilitas Jamkesda (Jaminan Kesehatan Daerah) dan Jamkesnas (Jaminan Kesehatan Nasional). Jamkesda adalah kebijakan jaminan bantuan pembayaran biaya kesehatan yang dialokasikan oleh Pemerintah Kabupaten (Pemkab) Cilacap kepada masyarakat Cilacap. Dananya bersumber dari APBD.

Pilar kedua disebut dengan "Cilacap Sehat". Untuk menunjang "Cilacap Sehat" itu, Pemkab Cilacap berencana membangun beberapa rumah 
sakit untuk mempermudah masyarakat mendapatkan akses layanan kesehatan. Pilar ketiga berkaitan dengan aspek ekonomi, yaitu peningkatan ketahanan pangan dan revitalisasi lumbung pangan masyarakat, peningkatan produk unggulan, dan spesifikasi daerah dengan penciptaan lapangan kerja di pedesaan, dan pengembangan Industri Kecil dan Menengah (IKM). Pilar keempat berkaitan dengan aspek sosial budaya. Kebijakannya adalah membangkitkan dan menumbuhkan jiwa gotong-royong dalam kehidupan bermasyarakat, terpelihara dan berkembangnya adat istiadat dan budaya lokal yang mendukung pembangunan, serta terpelihara dan berkembangnya seni lokal. Tampak bahwa program "Bangga Membangun Desa" yang ada di kabupaten Cilacap memilih fokus perhatian yang tidak lagi berorientasi pada kotak-kotak kegiatan per sektor, namun lebih berorientasi pda aspek kesejahteraan masyarakat secara luas. 
Tabel 1. Karakteristik Masyarakat Berdasarkan 5 Tahap Pembangunan Rostow

\begin{tabular}{|c|c|c|}
\hline NO. & TAHAP & INDIKATOR \\
\hline 1. & $\begin{array}{l}\text { Masyarakat Tradisional } \\
\text { (the traditional society }\end{array}$ & $\begin{array}{l}\text { - Pertanian padat tenaga kerja; } \\
\text { - Belum mengenal ilmu pengetahuan dan teknologi (era } \\
\text { Newton) } \\
\text { - Ekonomi mata pencaharian; } \\
\text { - Hasil-hasil tidak disimpan atau diperdagangkan; dan } \\
\text { - Adanya sistem barter. }\end{array}$ \\
\hline 2. & $\begin{array}{l}\text { Pembentukan prasyarat } \\
\text { tinggal landas } \\
\text { (the preconditions for } \\
\text { takeoff) }\end{array}$ & $\begin{array}{l}\text { - Pendirian industri-industri pertambangan; } \\
\text { - Peningkatan penggunaan modal dalam pertanian; } \\
\text { - Perlunya pendanaan asing; } \\
\text { - Tabungan dan investasi meningkat; } \\
\text { - Terdapat lembaga dan organisasi tingkat nasional; } \\
\text { - Adanya elit-elit baru } \\
\text { - Perubahan seringkali dipicu oleh gangguan dari luar. }\end{array}$ \\
\hline 3. & $\begin{array}{l}\text { Tahap tinggal landas (the } \\
\text { take-off) }\end{array}$ & $\begin{array}{l}\text { - Industrialisasi meningkat; } \\
\text { - Tabungan dan investasi semakin meningkat; } \\
\text { - Peningkatan pertumbuhan regional; } \\
\text { - Tenaga kerja di sektor pertanian menurun; } \\
\text { - Stimulus ekonomi berupa revolusi politik, } \\
\text { - Inovasi teknologi, } \\
\text { - Perubahan ekonomi internasional, } \\
\text { - Laju investasi dan tabungan meningkat 5-10 persen dari } \\
\text { - } \quad \text { Sendapatan nasional } \\
\text { - Pengaturan kelembagaan (misalnya sistem perbankan). }\end{array}$ \\
\hline 4. & $\begin{array}{l}\text { Pergerakan menuju } \\
\text { kematangan ekonomi (the } \\
\text { drive to maturity) }\end{array}$ & $\begin{array}{l}\text { - Pertumbuhan ekonomi berkelanjutan; } \\
\text { - Diversifikasi industri; } \\
\text { - Pembangunan di sektor-sektor baru } \\
\text { - Penggunaan teknologi secara meluas } \\
\text { - Investasi dan tabungan meningkat } 10-20 \text { persen } \\
\text { daripendapatan nasional. }\end{array}$ \\
\hline 5. & $\begin{array}{l}\text { Era konsumsi-massal } \\
\text { tingkat tinggi (the age of } \\
\text { high mass-consumption) }\end{array}$ & $\begin{array}{l}\text { - Proporsi ketenagakerjaan yang tinggi di bidang jasa; } \\
\text { - Meluasnya konsumsi atas barang-barang yang tahan lama } \\
\text { dan jasa } \\
\text { - peningkatan belanja jasa-jasa }\end{array}$ \\
\hline
\end{tabular}

Sumber: diadaptasi dari Adzani, 2012

\section{Kawasan Industri Kabupaten/Kota}

Terkait dengan teori pembangunan yang menunjuk pada pergeseran dominasi sektor ekonomi dari usaha primer/pertanian ke sektor industri dan jasa, maka melalui regulasi Keputusan Presiden Nomor 41 tahun 1996 ditetapkan kebijakan yang berkaitan 
dengan Pengembangan Kawasan Industri di Indonesia. Menurut regulasi ini, disebutkan bahwa Kawasan industri adalah suatu daerah yang didominasi oleh aktivitas industri yang mempunyai fasilitas kombinasi terdiri dari peralatanperalatan pabrik (industrial plants), sarana penelitian dan laboratorium untuk pengembangan, bangunan perkantoran, bank, serta fasilitas sosial dan fasilitas umum. Dalam perkembangannya, ditetapkan Peraturan Pemerintah Nomor 24 Tahun 2009, yang menyatakan bahwa tujuan pembangunan kawasan industri adalah untuk (a) mengendalikan pemanfaatan ruang; (b) meningkatkan upaya pembangunan Industri yang berwawasan lingkungan; (c) mempercepat pertumbuhan Industri di daerah; (d) meningkatkan daya saing Industri; (e) meningkatkan daya saing investasi; dan (f) memberikan kepastian lokasi dalam perencanaan dan pembangunan infrastruktur, yang terkoordinasi antar sektor terkait (Pasal 2).

Agar Kawasan Industri dapat berjalan dengan baik, maka pemerintah menetapkan suatu Kawasan Peruntukan Industri, yaitu suatu bentangan lahan yang diperuntukkan bagi kegiatan Industri berdasarkan Rencana Tata Ruang Wilayah yang ditetapkan sesuai dengan ketentuan peraturan perundangundangan. Tanggungjawab pelaksanaan kegiatan pada Kawasan Industri yang bersangkutan berada pada Perusahaan Kawasan Industri (Pasal 1).

Peraturan Pemerintah ini ternyata juga mewajibkan Perusahaan Kawasan Industri untuk juga menjediakan lahan bagi usaha Mikro, Kecil, dan Menengah (Pasal 20). Dengan demikian Kawasan Industri seyogyanya juga menunjukkan suatu keseimbangan perhatian Pemerintah kepada industri skala besar maupun bagi industri dalam skala UMKM.

Secara bertahap mulai dikembangkan Kawasan Industri di Indonesia. Kawasan yang pertama dibangun adalah Jakarta Industrial Estate Pulo Gadung (JIEP) pada tahun 1973 (Kwanda, 2000). Kemudian berturutturut dikembangkan Surabaya Industrial Estate Rungkut (SIER) dan Kawasan Industri Cilacap pada tahun 1974, Kawasan Industri Medan pada tahun 1975, Kawaasan Industri Makasar pada tahun 1978, Kawasan Industri Cirebon pada tahun 1984, serta Kawasan Industri Lampung pada tahun 1986.Terdapat perkembangan yang berbeda-beda untuk satu Kawasan Industri dengan kawasan industri yang lainnya.

Syahruddin (2010) menemukan bahwa terkait dengan pengembangan Kawasan Industri di kabupaten Karawang, pihak-pihak terkait dari jajaran pemerintahan cenderung untuk bekerja sendiri-sendiri, tanpa menunjukkan indikasi upaya untuk secara terkoordinasi menyelenggarakan kegiatan pembinaan dan pengembangan kawasan industri yang ada. Pelayanan birokrasi juga dinilai masih belum profesional, serta tidak didukung oleh penggunaan peralatan teknologi IT yang memadai. Disamping itu ditemukan pula adanya keterbatasan dalam hal sumber daya manusia yang memiliki kompetensi memadai untuk menunjang kegiatan di kawasan industri, sementara infrastruktur penunjang juga dinilai masih harus terus disempurnakan, baik jumlah maupun kualitasnya. 
Pengembangan Industri di Kabupaten Karawang

Posisi kabupaten Karawang yang berada di antara Jakarta dan Cirebon, serta dapat diakses dari tol JakartaCikampek dan Cikampek-Palimanan merupakan kelebihan yang dinikmati oleh kabupaten Karawang.Kabupaten ini merupakan salah satu kabupaten yang memiliki kawasan industri terbesar di Indonesia dan Asia Tenggara ( 19.000 Ha), untuk saat ini ada 5 (lima) kawasan industri yang sudah beroperasi.Kawasan industri sudah ditempati oleh berbagai macam perusahaan baik nasional ataupun internasional dan sudah menyerap ribuan pekerja.

Terdapat 5 (lima) kawasan Industri di Kabupaten Karawang: (1) kawasan Industri Indotaisei, kec. Cikampek; (2) kawasan Industri KIIC, Tec. Teluk Jambe, seluas 1200 ha.; (3) kawasan Industri Mitra Karawang, kec. Ciampel, seluas sekitar 500 ha.; (4) kawasan Industri Timor Putra Nasional, Dawuan; dan (5) kawasan Industri Kujang,kec. Cikampek, yang merupakan anak perusahaan PT Pupuk Kujang, seluas 140 ha. Terlihat bahwa lebih dari 2000 ha lahan telah digunakan untuk mendukung pengembangan kawasan-kawasan Industri yang ada di Kabupaten Karawang.

Dalam kaitannya dengan konversi lahan sawah untuk keperluan industri, Erviani (2011) menemukan bahwa konversi lahan sawah sebagai akibat dari pengembangan kawasan Industri di Karawang, telah menurunkan tingkat keunggulan kompetitif usahatani beras di Kabupaten Karawang. Hal ini terutama diakibatkan oleh adanya peningkatan biaya sewa lahan dan upah tenaga kerja yang terjadi sebagai akibat dari adanya konversi lahan sawah. Namun demikian, berdasarkan Peraturan Daerah Kabupaten Karawang No. 2 tahun 2013 tentang RTRW Kabupaten Karawang tahun 2011-2031, alih fungsi lahan tersebut memang telah memiliki landasan legal formal. Pasal 5 ayat 4 peraturan ini, misalnya, menyatakan bahwa pemanfaatan ruang di kawasan peruntukan industri diarahkan ke kecamatan Cikampek, Telukjambe Barat, Telukjambe Timur, Klari, Ciampel, Karawang Barat, Karawang Timur, Pangkalan, dan Rengasdengklok. Namun demikian dalam Pasal 57 ayat 6 dinyatakan bahwa setiap kawasan Industri harus menyediakan RTH publik setidaknya 20 persen dari seluruh luas kawasan.

\section{Persepsi Kepala Desa di Kawasan Industri Karawang}

Kecamatan Klari merupakan salah satu kecamatan yang ditetapkan Kabupaten Karawang sebagai lokasi kawasan Industri, sehingga dipilih sebagai ilustrasi untuk keperluan kajian ini. Kecamatan Klari terdiri atas 13 desa yang merupakan bagian dari kabupaten Karawang, dengan luas wilayah 5.937 Ha, meliputi: lahan sawah $2.392 \mathrm{Ha}$, lahan darat 3.545 Ha (Utami, 2014). Jumlah penduduk kecamatan Klari berjumlah 140.773 jiwa terdiri dari 70.936 laki-laki, 69.837 perempuan, 43.728 Kepala Keluarga dengan mata pencaharian sebagian besar penduduk bergerak dalam: (1) Sektor pertanian 9.784 RTP mencakup bidang; pertanian tanaman pangan padi sawah, hortikultura, peternakan, dan perkebunan; (2) Sektor Perikanan 225 RTP mencakup bidang; budidaya air tawar; (3) Sektor Kehutanan 683 RTP. 
Secara purposif dipilih 4 (empat) desa untuk dianalisis lebih lanjut: desa Duren, desa Pancawati, desa Curug, dan Desa Cimahi. Ketiga desa dipilih karena letaknya yang berdekatan dengan kawasan industri di Karawang. Dipilih juga dua desa secara purposif sebagai pembanding, mengingat lokasinya yang secara relatif jauh dari daerah kawasan industri: desa Sukasari dan desa Kedung Jaya di Kecamatan Cibuaya.

Para Kepala Desa diminta memberikan tanggapan dan pendapat atas beberapa pokok bahasan utama: (1) Penilaian terhadap perkembangan kecamatan, (2) penilaian tentang kemajuan desa yang dipimpin dibandingkan dengan desa-desa lain di kecamatan yang sama, (3) penilaian tentag perkembangan kemajuan desa dalam 10 tahun terakhir, (4) pandangan tentang kapasitas SDM desa, (5) pandangan tentng 3 kegiatan prioritas yang diperlukan oleh desa, (6) interaksi desa dengan pihak kabupaten Karawang dan industri ataupun perusahaan setempat, (7) serta pandangan tentang peluang pengembangan kegiatan perikanan di desa yang bersangkutan. Berikut disajikan tanggapan para Kepala Desa tentang pokok-pokok bahasan tersebut.

\section{Desa Duren}

Desa Duren merupakan penghasil produksi ikan lele terbesar di Kecamatan Klari. Desa Duren merupakan desa yang memiliki sumber daya alam yang cukup meskipun sebagian besar wilayahnya dipadati oleh penduduk (Utami, 2014). Sumber daya alam yang tersedia di desa Duren diantaranya, yaitu $79 \mathrm{Ha}$ sawah dan 1,65 Ha tanah empang. Dari 1,65 Ha tanah empang yang berpotensi di bidang perikanan khususnya di bidang perikanan budidaya baru sekitar $\pm 0,2$ Ha yang dimanfaatkan sebagai wadah budidaya perikanan. Selain itu, desa Duren juga memiliki sungai dan danau sebagai sumber air untuk usaha perikanan.

Dibandingkan dengan kecamatankecamatan lain di Kabupaten Karawang, Kecamatan Klari termasuk kecamatan yang lebih maju, dapat dilihat dalam segi industri, tenagakerja, pendidikan, dan penduduk. Sekarang ini banyak berdirinya industri di Kecamatan Klari. Pendidikan masyarakat minimal 9 tahun. Penduduk Kecamatan Klari semakin meningkat seiring dengan banyak berdirinya perumahan-perumahan. Apabila dibandingkan dengan desa-desa lain di Kecamatan Klari, Desa Duren termasuk desa yang biasa-biasa saja, karena terdapat banyaknya penduduk. Aktifitas warga lebih kepekerjaan nonpertanian dibandingkan aktivitas pertanian.

Dibandingkan dengan keadaan sekitar 10 tahun yang lalu, Desa Duren mengalami perkembangan yang lebih maju dalam berbagai macam infrastruktur, pendidikan (minimal 9 tahun, dan sudah ada perguruan tinggi) dan pekerjaan. Contoh dalam hal infrastruktur, telah terdapat perkembangan sarana pendidikan (sudahada saat ini 5 SLTA), fasilitas keagamaan (TPA, mesjid, dan majelis taklim), kesehatan (biaya gratis untuk warga miskin), serta berkembangnya aktivitas ekonomi kerakyatan karena terjadinya urbanisasi. Sumberdaya manusia yang ada di Desa Duren dapat dikatakan cukup memadai untuk menjadi penggerak pembangunan di desa, karena Desa Duren dapat menampung tenaga 
kerja yang cukup banyak, sebagai dampak dari banyaknya industri di Kecamatan Klari.

Desa Duren bukan desa di wilayah Kawasan Industri, tetapi Desa Duren dikatakan sebagai bagian dari zona industri terpadu. Mengacu pada Perda Kabupaten Karawang No. 2 Tahun 2013, disebutkan bahwa Kabupaten Karawang mengembangkan Kawasan Industri (kawasan tempat pemusatan kegiatan Industri yang dilengkapi dengan sarana dan prasarana penunjang yang dikembangkan dan dikelola oleh Perusahaan Kawasan Industri yang telah memiliki Izin Usaha Kawasan Industri) dan Kawasan peruntukan industri (bentangan lahan yang diperuntukkan bagi kegiatan industri berdasarkan Rencana Tata Ruang Wilayah yang ditetapkan sesuai dengan ketentan peraturan perundang-undangan). Dinilai bahwa yang dimaksud oleh Kepala Desa Duren dalam hal ini adalah Kawasan Peruntukan Industri, mengingat di desa Duren hanya terdapat 6 (enam) perusahaan saja, bukan dalam kawasan industri. Kelebihan Desa Duren sebagai zona industri terpadu adalah bahwa industri-industri yang ada dapat mempekerja dari lingkungan sekitar, sementara limbah yang ada dapat dimanfaatkan dan diolah secara ekonomis.

Dalam pengamatan dan catatan pemerintahan Desa Duren, industri yang ada di Desa Duren mampu menyerap tenaga kerja sekitar setengah dari penduduk Desa Duren. Penyerapan tenaga kerja dari desa oleh industri di sekitar desa ini sama sekali tidak menjadi hambatan karena adanya sifat saling memerlukan antara masyarakat desa dengan industri-industri yang ada.
Hubungan antara perintahan Desa Duren dengan industri-industri tersebut juga berjalan dengan baik.

Dalam hal pembangunan Desa Duren, ada 3 hal yang menjadi prioritas atau diutamakan untuk dikembangkan, yaituKeagamaan (pembangunan sarana keagamaan, seperti majelis taklim, masjid, TPA), Infrastruktur Jalan, dan Pendidikan.Pengembangan di bidang perikanan dinilai cukup memiliki peluang positif. Hal ini mengingat permintaan pasar untuk perikanan berupa daging dan benih ikan sangat tinggi; Kepala Desa memperkirakan bahwa untuk ikan segar sekitar 6 ton per minggu dan untuk benih 600.000 ekor. Dengan demikian terbuka peluang bagi pengembangan budidaya maupun perdagangan ikan di desa ini.

\section{Desa Pancawati}

Dalam pandangan Kepala Desa Pancawati, dibandingkan dengan kecamatan-kecamatan lain di Kab. Karawang, Kecamatan Klari merupakan Kecamatan yang lebih maju, karena sebagian besar penduduknya mempunyai penghasilan diatas UMK (Rp.2.400.000) (Kadavi, 2014). Kecamatan Klari merupakan wilayah peruntukan industri yang memiliki banyak pabrik sehingga dapat membuka lapangan pekerjaan terhadap masyarakat di Kecamatan Klari itu sendiri. Kecamatan Klari juga berada di dekat Kota karawang dimana akses dalam distribusi kebutuhan pokok, industri maupun rumah tangga menjadi lebih mudah.

Dibandingkan dengan desa lain di Kecamatan Klari, desa Pancawati termasuk desa yang lebih maju. Hal ini karena letak geografis desa Pancawati yang berada dekat dengan pusat 
pemerintahan kecamatan Klari. Dari sektor industri pabrik maupun pertanian di desa Pancawati merupakan desa yang lebih maju dibandingkan dengan desa lainnya. Dari segi pendapatan masyarakat desa juga sudah baik. Dalam pandangan Kepala Desa Pancawati, baik petani maupun buruh sebagai bagian dari masyarakat desa Pancawati memiliki penghasilan diatas UMK.

Dibandingkan dengan keadaan sekitar 10 tahun yang lalu, desa Pancawati mengalami perkembangan yang berarti. Perkembangan tersebut terutama berupa infrastruktur jalan, pekerjaan infrastruktur jembatan, pekerjaan rehabilitasi bangunan desa, dan bantuan ekonomi kepada petani. Dalam pada itu menurut Kepala Desa Pancawati, Sumberdaya Manusia yang ada di desa Pancawati cukup memadai untuk menjadi pengerak pembangunan desa. Hal yang dinilai perlu terus dikembangkan adalah adanya kerjasama yang baik dari pihak-pihak terkait untuk mengembangkan desa dengan mengadakan pelatihan, keterampilan dan kursus kepada masyarakat.

Aparat desa Pancawati belum pernah mendapatkan penjelasan dari kabupaten maupun kecamatan bahwa desa Pancawati merupakan desa di wilayah industri.Kelebihan desa Pancawati ini sebagai desa dikawasan peruntukan industri adalah dengan adanya banyak perusahaan atau pabrik maka secara langsung akan menyerap tenaga kerja dari masyarakat di desa Pancawati, meningkatkan pendapatan desa yaitu dari pajak pabrik, serta mempercepat pembangunan yang ada di desa Pancawati. Kelemahannya adalah bahwa keberadaan banyak pabrik tersebut mengakibatkan bertambahnya intensitas polusi, baik polusi udara, tanah mapun air. Perairan di desa Pancawati menjadi tercemar akibat limbah. Selain itu akibat adanya banyak pabrik sering terjadi konflik sosial antara warga yang memperebutkan limbah atau barang sisa dari kegiatan produksi pabrik.

Industri yang ada di sekitar desa ini menyerap sekitar $60 \%$ tenaga kerja yang berasal dari desa Pancawati. Faktor penghambat penyerapan tenaga kerja di desa Pancawati adalah SDM dari masyarakat itu sendiri, terutama dari sisi pendidikan, pengalaman dan skill yang rendah.

Interaksi antara kepala desa dengan industri-industri yang ada di wilayah desa Pancawti adalah dari segi perpajakan. Setiap industri yang ada wajib dikenakan pajak kepada pihak desa Pancawati dan adanya kontribusi pabrik untuk kegiatan rutin desa.

Tiga prioritas pembangunan yang perlu dilakukan di desa Pancawati adalah infrastruktur, Ekonomi, dan kesehatan. Dari sisi infrastruktur yang diperlukan adalah pembangunan jalan dan bangunan. Dari sisi ekonomi yaitu upaya peningkatan pendapatan masyarakat dan membuka lapangan pekerjaan bagi warga dengan adanya pabrik, dan dengan upaya menumbuhkan kegiatan usaha perikanan kepada masyarakat sebagai penghasilan tambahan dan upaya pemenuhan kebutuhan pangan di desa Pancawati. Faktor kesehatan yaitu mencakup upaya agar setiap warga desa Pancawati dapat memperoleh pelayan kesehatan.

Dalam pandangan Kepala Desa Pancawati, kegiatan perikanan di desa ini dapat menjadi salah satu pilihan utama meningkatkan pendapatan dan 
kesejahteraan masyarakat desa, namun kegiatan perikanan yang diharapkan adalah usaha pengolahan ikan. Hal ini mengingat kegiatan budidaya ikan di desa Pancawati menghadapi masalah karena adanya pencemaran air oleh limbah pabrik. Hal yang paling memungkinkan adalah pengolahan hasil perikanan untuk memenuhi kebutuhan bahan makanan bagi para karyawan pabrik yang ada di sekitar desa Pancawati, maupun untuk masyarakat desa Pancawati sendiri.

\section{Desa Cimahi}

Kepala Desa Cimahi menilai bahwa Kecamatan Klari merupakan kecamatan yang termasuk maju di Kabupaten Karawang, baik dari sisi SDM, perekonomian, tingkat pengangguran, infrastuktur kecamatan dan fasilitas pendukung kecamatan (Koriawan, 2014). Dilihat dari segi SDM masyarakat kecamatan Klari rata-rata baik, serta dari segi ekonomi masyarakat Klari cukup bagus karena klari merupakan zona industri sehingga mampu memberikan lapangan pekerjaan bagi masyarakat klari, selain itu infrastruktur seperti jalan dan listrik di kecamatan klari sudah memadai keseluruh desa di Kecamatan Klari.

Begitu pula Desa Cimahi dinilai cukup maju jika dibandingkan dengan desa lainnya di kecamatan Klari maupun Kabupaten Karawang. karena masyarakat desa Cimahi rata-rata memiliki pekerjaan yang tetap yaitu di bidang Industri mengingat desa Cimahi juga masuk ke dalam Zona Industri. Dengan meningkatnya perekonomian, maka meningkat pula SDM masyarakat Cimahi terutama di bidang pendidikan, Di bidang pendidikan di desa Cimahi saat ini telah ada Sekolah Menengah Kejuruan yang dapat menyetarakan tingkat pendidikan masyarakat Cimahi dengan masyarakat sekitarnya. Selain itu dibandingkan dengan 10 tahun lalu desa Cimahi telah mengalami banyak peningkatan dimana telah tumbuh banyak lapangan pekerjaan bagi masyarakat setelah tumbuhnya industri di desa Cimahi. Dampak selanjutnya adalah berkembanngnya industri perumahan yang muncul, rumah makan, tempat kos, rumah kontrakan, serta tempat penitipan motor.

Berkembangnya desa Cimahi sebagai lokasi zona industri telah dikomunikasikan oleh Camat Klari. Kepala Desa Cimahi menilai bahwa hal ini akan dapat membantu perekonomian masyarakat dimana warga akan memiliki lapangan pekerjaan yang lebih banyak, meskipun mengakibatkan tergesernya lahan pertanian milik warga. Kemudian kelebihan dari zona industri ini adalah semakin meningkatnya perekonomian, penghasilan meningkat, tidak ada pengangguran, hampir $80 \%$ masyarakat usia produktif diserap oleh industri sebagai tenaga kerja. Hambatan dalam penyerapan tenaga kerja ini adalah tingkat pendidikan masyarakat des Cimahi yang masih rendah, sehingga hanya diterima bekerja sebagai tenaga kerja kasar saja (tenaga kuli). Namun demikian Kepala Desa menyadari dampak negatif yang ditimbulkan, yaitu tidak ada lagi lahan pertanian yang memadai, kondisi udara menjadi lebih jelek akibat polusi, kebisingan oleh pabrik, dan jalanan cepat rusak akibat banyaknya mobil-mobil berat yang melewatinya. 
4. Desa Sukasari, Kecamatan Cibuaya

Dalam pandangan Kepala Desa Sukasari, Kecamatan Cibuaya lebih tertinggal dibandingkan dengan kecamatan lain, karena Infrastruktur jalan dari tiap-tiap desa di kecamatan Cibuaya baru mencapai 50\% jalanan yang baru diperbaiki dan sisanya masih rusak dan kurang baik (Andrea, 2014). Kualitas SDM yang ada juga masih rendah. Disamping itu masih terdapat 3 desa yang termasuk dalam kategori IDT (Integritas Desa Terisolisir) adalah Desa Sukasari, Desa Kalidung Jaya dan Desa Gebang Jaya.

Di sisi lain, Kepala Desa Sukasari menilai bahwa telah terjadi cukup banyak perubahan di desa Sukasari dalam 10 tahun terakhir. Perkembangan yang terjadi diantaranya :

1. Fasilitas sekolah SMP dan SMA sehingga masyarakat dapat mengenyam pendidikan yang lebih baik dan tidak perlu harus keluar desa.

2. Infrastruktur jalan bertambah, walaupun baru $30 \%$

3. Kantor Desa sudah dibangun sehingga dapat memudahkan Kepala desa untuk menyampaikan informasi dalam rapat mingguan dan lain lain.

4. Dalam bidang perikanan, layanan pendukung seperti jalan dapat mudah digunakan sehingga dalam kendaraan dapat melakukan kegiatan pemasarn dengan baik dan lancar.

5. Dalam pertanian, saluran air yang sudah dibuat sehingga dapat berfungsi lebih baik.

6. Pada umumnya masyarakat Desa Sukasari mempunyai perekonomian yang cukup baik karena dilihat dari hasil perdagangan olahan ikan, warung-warung kecil dan hasil pertanian cukup baik.

7. jalanan gang sudah dibangun walaupu baru $70 \%$

8. Rumah masyarakat cukup baik karena dibantu dari hasil TKI dan Olahan pindang

Perkembangan SDM dinilai Kepala Desa kurang memadai. Untuk itu diperlukan 3 (tiga) prioritas kegiatan sesuai dengan kondisi SDM yang ada, yaitu di bidang Infrastruktur, pengembangan perikanan, serta pembangunan pertanian. Hal ini sesuai dengan keadaan lahan yang potensial bagus bagi desa sukasari dan mayoritas penduduk desa lebih dari $40 \%$ sebagai pengolah/pedagang ikan pindang.

Dari deskripsi tentang desa-desa diatas, tampak bahwa secara umum desa-desa di lokasi yang berdekatan dengan kawasan peruntukan industri secara umum memiliki 2 (dua) situasi yang bertentangan satu sama lain. Di satu sisi desa-desa tersebut memiliki keuntungan dan menikmati manfaat dari keberadaannya yang dekat dengan lokasi peruntukan industri, yautu dengan penyerapan tenaga kerja desa yang bersangkutan, serta berkembangnya aktivitas ekonomi desa dalam bentuk munculnya rumah makan, penitipan kendaraan bermotor, samai pada aberkembangnya infrastruktur jalan dan bangunan. Disisi lain, polusi dalam berbagai bentuk menjadi masalah yang harus dihadapi oleh desa-desa tersebut, sementara kegiatan pertanian dan perikanan menjadi berkurag intensitasnya karena adanya alih fungsi lahan maupun terganggunya pasokan air yang diperlukan untuk aktivitas-aktivitas tersebut. Para Kepala Desa memiliki posisi strategis untuk dapat menjadi 
"pengaman" masalah-masalah yang dihadapi itu, meskipun dalam beberapa hal mereka tidak dalam posisi memiliki kewenangan untuk langsug menangani masalah yang dihadapi, karena kewenangan berada pada pihak atasan desa-desa itu.

Bagi desa-desa yang tidak berdekatan dengan kawasan peruntukan industri (dalam hal ini Desa Sukasari), perkembangan desa yang terjadi tidaklah secepat desa-desa yang berada dalm lingkungan kawasan peruntukan industri. Infrastruktur jalan dan bangunan menjadi faktor pembeda yang utama, disamping faktor kesempatan ekonomi bagi penduduknya. Di sisi lain, desadesa ini tidak harus mengalami dampak seperti tingginya tingkat polusi, sementara aktivitas kegiatan primer seperti pertanian dan perikanan masih dapat berjalan tanpa hambatan yang berarti.

\section{KASIMPULAN DAN SARAN}

\section{Kesimpulan}

1. Konsep dasar Teori Pembangunan suatu negara yang dimotori oleh Rostow telah menjadi salah satu acuan bagi negara-negara berkembang seperti Indonesia didalam melaksanakan proses pembangunan negara-negara tersebut. Perkembangan pembangunan yang dicirikan oleh bergesernya kontribusi aktivitas primer seperti pertanian dan perikanan ke aktivitas sekunder dan tersier merupakan dinamika yang dialami oleh negara-negara berkembang sampai saat ini. Negara-negara maju di Amerika dan Eropa, dengan berbagai corak dan versi masig-masing, juga diwarnai oleh dinamika perkembangan pergeseran kontribusi aktivitasaktivitas tersebut untuk sampai kepada status sebagai negara maju.

2. Pendekatan pembangunan dengan pendekatan dinamika pergeseran antar sektor perekonomian diwujudkan dalam penetapan Kawasan Industri maupun Kawasan Peruntukan Industri pada beberapa Propinsi dan Kabupaten/Kota yang ada di Indonesia. Disamping manfaat yang diperoleh dari sisi percepatan pembangunan, penyerapan tenaga kerja, penambahan fasilitas infrastruktur, maupun peningkatan pendapatan daerah, penetapan tersebut juga berdampak pada perubahan pemanfaatan lahan, serta terjadinya polusi sebagai akibat berkembangnya industri. Kondisi ini menuntut perhatian pihak pemerintah setempat untuk mengambil langkahlangkah mengatasi dampak yang tidak dikehendaki tersebut.

3. Kabupaten Karawang merupakan salah satu kabupaten yang ditetapkan sebagai basis pengembangan Industri di Jawa Barat. Melalui Peraturan Daerah No. 2 Tahun 2013 telah ditetapkan lokasi-lokasi untuk Kawasan Industri maupun Kawasan Peruntukan Industri. Sejumlah Kawasan Industri maupun Kawasan Peruntukan Industri telah berkembang di Kabupaten Karawang, sehingga Karawang terbentuk menjadi salah satu sentra Industri di Jawa Barat. Lebih dari 2000 ha lahan terkonversi dari lahan sawah atau lahan pertanian menjadi lahan peruntukan industri. Sedikit 
banyak hal ini dinilai akan berpengaruh bagi Karawang sebagai salah satu pemasok produksi pangan terbesar di Jawa Barat.

4. Kepala Desa di desa-desa di lokasi Kawasan Peruntukan Industri atau berdekatan dengan Kawasan Industri menilai bahwa cukup banyak manfaat dari keberadaan kawasankawasan tersebut kepada desa dan masyarakat desa dalam kurun waktu 10 tahun terakhir, baik dari sisi penyerapan tenaga kerja, berkembangnya kegiatan perekonomian desa, maupun tambahan infrastruktur yang dapat dinikmati masyarakat desa. Namun desa-desa tersebut juga mengalami dampak negatif, terutama berkaitan dengan makin berkurangnya lahan untuk pertanian dan perikanan, serta polusi yang timbul dengan adanya industri-industri tersebut. Desa-desa yang relatif jauh dari kawasan tidak merasakan dampak langsung dari keberadaan kawasan untuk industri; desa-desa ini mendapatkan manfaat tidak langsung, yaitu dengan adanya pengembangan sarana dan prasarana penunjang transportasi, jalan, serta pendidikan.

\section{Saran}

1. Kebijakan dan strategi pembangunan yang bersentuhan langsung dengan kepentingan Desa perlu disusun dengan semangat Win-win Solution, sehingga pihak-pihak yang terkait mendapatkan manfaat dari kebijakan dan strategi tersebut, termasuk pihak Desa lokasi dari implementasi kebijakan dan strategi pembangunan tersebut. Kebijakan dan strategi pembangunan yang berorientasi kepada pengembangan industri dengan demikian harus memperhatikan dampak dan pengaruhnya terhadap tata kehidupan masyarakat desa lokasi pengembangan industri yang bersangkutan.

2. Mengingat pengembangan industri di wilayah pedesaan selalu memiliki dampak negatif disamping dampakdampak positifnya, kebijakan pengembangan industri di wilayah pedesaan harus didasarkan pada upaya untuk memperbesar dampak positifnya serta menekan sebanyak mungkin dampak negatif yang akan ditanggung masyarakat pedesaan. Dengan cara itu masyarakat desa tidak harus sekedar menjadi "penonton" dari pengembangan industri yang dilakukan.

3. Pelibatan pihak desa sejak awal perencanaan pengembangan industri di wilayah pedesaan perlu dilakukan secara partisipatif, sehingga masyarakat desa dapat memahami dan bahkan mendukung rencana pengembangan yang akan dilakukan. Dengan mekanisme ini diharapkan pengetahuan dan persepsi masyarakat desa, melalui keberadaan dan komunikasi dengan Kepala Desa masing-masing, dapat diadopsi secara optimal dalam proses pengembangan industri tersebut. Hal ini diharapkan dapat menjadi faktor penunjang pengembangan industri yang bersangkutan, sambil secara optimal dapat menekan dampakdampak negatif seperti polusi dan konversi lahan yang masih dalam batas-batas dapat diteria masyarakat desa yang bersangkutan. Sejumlah rekomendasi pengawalan 
pembangunan di pedesaan yang telah dikemukakan terdahulu dapat menjadi bahan pertimbangan bagi para penentu kebijakan.

\section{DAFTAR PUSTAKA}

Adzani, Hamada. 2012. Analisa dan Kritik Teori Modernisasi: Kritik terhadap 5 Tahap Pembangunan W. W. Rostow. FISIP UGM. Yogyakarta.

Andrea, Giri. 2014. Penyusunan Dan Pembuatan Media Penyuluhan Dalam Penyelenggaraan Penyuluhan PerikananDi Desa Sukasari Kec. Cibuaya Kab. KarawangProvinsi Jawa Barat. Laporan PKL III. Jurusan Penyuluhan Perikanan STP. Bogor.

Erviani, Anggun Eka. 2011. Dampak Konversi Lahan Sawah terhadap Keunggulan Kompetitif Usahatani Beras di Kabupaten Karawang. Skripsi. Departemen Ekonomi Sumberdaya dan Lingkungan. FEM IPB. Bogor.

Ishak S, Marenda. 2008. Identifikasi Pergeseran Sektor Unggulan Kecamatan Di Kabupaten Tasikmalaya Jawa Barat untuk Evaluasi Kebijakan Pertanian. Jurnal Agrikultura. Vol. 19 No. 3.

Kadavi, Muhammad. 2014. Sistem Penyuluhan PerikananDesa Pancawati Kecamatan Klari Kabupaten Karawang Provinsi Jawa Barat.Laporan PKL III. Jurusan Penyuluhan Perikanan STP. Bogor.
Kariyasa, 2006. Perubahan Struktur Ekonomi dan Kesempatan Kerja serta Kualitas Sumberdaya Manusia di Indonesia. PSEKP. Bogor.

Koriawan, IW Deni. 2014. Penyelenggaraan Kegiatan Penyuluhan di desa Cimahi Kecamatan Klari Kabupaten Karawang. Laporan PKL III. Jurusan Penyuluhan Perikanan STP. Bogor.

Kwanda, $\quad 2000$. Pengembangan Kawasan Industri di Indonesia. Jurnal Dimensi Teknik Arsitektur, Vol.28, No.1.

Pambudi, Andi Tri. 2011. Pergeseran Struktur PerekonomianAtas Dasar Penyerapan Tenaga Kerja Di Provinsi Jawa Tengah. Skripsi Jurusan Ilmu Ekonomi dan Studi Pembangunan. Universitas Diponegoro. Semarang.

Rostow, W. W. 1960. The Stages of Economic Growth: A NonCommunist Manifesto Cambridge University Press. Cambridge.

Syahruddin. 2010. Evaluasi Implementasi Kebijakan Pengembangan Kawasan Industri Bisnis \& Birokrasi: Jurnal Ilmu Administrasi dan Organisasi, JanApr 2010, hlm. 31-43 Volume 17, Nomor 1.

Utami, Slamet Oki. 2014. Penyelenggaraan Penyuluhan PerikananDi Kecamatan Klari Kabupaten KarawangProvinsi Jawa Barat. Laporan PKL III. Jurusan Penyuluhan Perikanan STP. Bogor. 